(C) Inra/Elsevier, Paris

Original article

\title{
Uptake of Cd and Ni by spinach, Spinacea oleracea (L.) from polluted soil under field conditions as affected by salt water irrigation
}

\author{
Mohamed Helal*, Ermek Baibagyshew, Salah Saber \\ Institute of Agroecology, Federal Agricultural Research Center (FAL), Bundesallee 50, 38116 Braunschweig, Germany
}

(Received 15 June 1998; accepted 11 August 1998)

\begin{abstract}
Both heavy metal pollution and soil salinization are increasing in dry areas. Nevertheless, salinity-heavy metal interactions in soils and crops are not well understood. This work aimed at evaluating the effect of salt water irrigation on the uptake of $\mathrm{Cd}$ and $\mathrm{Ni}$ by spinach from a polluted soil under field conditions at the Nahda project site, northwest of Egypt. Microplots were irrigated either with water or with salt solution $\left(0.8 \mathrm{~g} \cdot \mathrm{L}^{-1}\right)$ for 9 weeks. Subsequently, the plants were harvested for root evaluation and plant as well as soil chemical analysis. Salt water irrigation stimulated root development and enhanced the extractability of $\mathrm{Cd}$ and $\mathrm{Ni}$ from soil as well as their uptake by spinach considerably. Possibly related interactions are discussed. The results suggest that the risk of leaching of heavy metals into surface waters and their transfer to the food chain in salt affected areas may be much greater than so far assumed. (@) Inra/Elsevier, Paris.)
\end{abstract}

spinach / cadmium / nickel / salinity / pollution

Résumé - Influence de l'irrigation à l'eau salée sur l'absorption de Cd et de Ni par l'épinard, Spinacea oleracea (L.), à partir d'un sol pollué, en conditions de plein champ. La pollution par les métaux lourds et la salinisation du sol sont en augmentation dans les régions sèches. Néanmoins les interactions salinité-métaux lourds dans les sols et les cultures sont mal comprises. Ce travail vise à évaluer l'effet de l'irrigation à l'eau salée sur l'absorption de Cd et de Ni par l'épinard à partir d'un sol pollué en conditions de plein champ sur le site Nahda, au nord-ouest de l'Égypte. Des microparcelles ont été irriguées soit avec de l'eau, soit avec une solution saline $\left(0,8 \mathrm{~g} \cdot \mathrm{L}^{-1}\right)$ durant neuf semaines. On a ensuite récolté les plantes pour évaluer le système racinaire et faire l'analyse chimique de la plante et du sol. L'irrigation à l'eau salée a stimulé le développement racinaire et considérablement augmenté l'extractibilité du Cd et du Ni du sol, ainsi que leur absorption par l'épinard. Les interactions possibles liées à ce phénomène sont discutées. Les résultats suggèrent que le risque de lessivage des métaux lourds dans les eaux de surface et leur transfert à la chaine alimentaire dans des régions touchées par le sel peuvent être beaucoup plus élevés qu'on ne le pensait jusqu'ici. (๑) Inra/Elsevier, Paris.)

épinard / cadmium / nickel / salinité / pollution

Communicated by Gérard Guyot (Avignon)

* Correspondence and reprints

E-mail: mohamed.helal@fal.de 


\section{INTRODUCTION}

Developing countries in dry areas are expanding agricultural food production on marginal land surrounding cities with major ecological problems. These include the lack of waste water treatment facilities, the scarcity of high quality irrigation water and increasing heavy metal pollution of soils and waters [13]. Considerable loads of salt and heavy metals from domestic and industrial origin therefore find their way into soils through the agricultural irrigation-drainage system. World wide, more than $30 \%$ of irrigated lands are affected by salinity [8]. A similar increase in heavy metal pollution on many sites has occurred during the last few decades due to increasing application of industrial materials and the lack of measures for pollution control [16]. The management of salt affected soils is well documented $[5,6,21,28]$. Similarly, the transfer of heavy metals from polluted soils to the food chain has been a subject of extensive research over the last few years [13, 19, 25, 27]. Nevertheless, scant attention has so far been devoted to the possible interaction between soil and water salinity and the transfer of heavy metals to crops. This is surprising because during recent years experimental evidence has accumulated (table I) which suggests that both the bioavailability of heavy metals in soils as well as several plant root functions are affected under saline conditions.
Table I summarizes some factors and processes which may be modified by soil salinity and are believed to be directly or indirectly involved in soil-plant heavy metal transfer under saline conditions. Some salt induced effects may have a positive $(+)$ effect, while others may induce a negative $(-)$ effect on metal fluxes in soil-plant systems. The overall effect on heavy metal uptake by plants is therefore hard to predict.

Against this background, this work aimed at evaluating the uptake of nickel and cadmium by spinach grown on a slightly heavy metal polluted field at Nahda, northwest of the Nile delta of Egypt, as affected by salt water irrigation.

\section{MATERIAL AND METHODS}

\subsection{Field experiment}

The project site Nahda, an alluvial sandy aridisol, was taken into production in 1958. Various ameliorative practices were carried out in order to remove excess salt and to improve soil fertility. These measures include the use of gypsum, leaching of salt, inclusion of leguminous green manure in the crop rotation and the application of composts occasionally enriched with canal sediments. Soil characteristics and heavy metal contents as well as their changes between 1972 and 1995 are summarized in table II.

Table I. Factors and processes related to heavy metal uptake by plants which may be modified by salinity.

Factors and processes
Potential effects on heavy metal fluxes
Metal concentration of soil solution

Sorption-desorption processes in soil

Release of root exudates

Root-microbial interactions, mycorrhiza

Length and configuration of root system, soil rooting density

Nutrient supply, nutrient-heavy metal interactions

Passive permeability of root membranes

Binding and exchange of heavy metals in root free space and xylem

Synthesis and turnover of organic carriers

Transpiration, growth rate, sink activity of shoot

$\begin{array}{cc}(+) & {[4,18]} \\ (+)(-) & {[3,24]} \\ (+) & {[13,17]} \\ (+)(-) & {[1,7]} \\ (+)(-) & {[13,15]} \\ (+)(-) & {[1,25]} \\ (+) & {[11,20]} \\ (+) & {[10,26]} \\ (+) & {[14,32]} \\ (-) & {[23,25]}\end{array}$

$(+),(-)$ : enhancing or depressing effects of salinity on corresponding processes. 
Table II. Soil characteristics, $\mathrm{Cd}$ and $\mathrm{Ni}$ contents at Nahda, Egypt and their change with time.

\begin{tabular}{lccc}
\hline Soil characteristics & 1972 & 1984 & 1995 \\
\hline \% clay & 11 & 16 & 17 \\
$\%$ silt & 21 & 24 & 25 \\
$\%$ sand & 68 & 60 & 58 \\
pH $\left(\mathrm{H}_{2} \mathrm{O}\right)$ & 8.2 & 7.7 & 7.8 \\
$\mathrm{CEC}\left(\mathrm{meq} \cdot 100 \mathrm{~g}^{-1}\right)$ & 13 & 17 & 21 \\
$\mathrm{EC} * *\left(\mathrm{dS} \cdot \mathrm{m}^{-1}\right)$ & 1.32 & 1.67 & 1.88 \\
$\%$ organic matter & 1.12 & 1.36 & 1.52 \\
Total Cd $\left(\mathrm{mg}^{-1} \mathrm{~kg}^{-1}\right)$ & 0.13 & 1.25 & 1.34 \\
Total Ni $\left(\mathrm{mg}^{-1} \mathrm{~kg}^{-1}\right.$ & 6.74 & 18.2 & 20.1 \\
\hline
\end{tabular}

* CEC: cation exchange capacity; ** EC: electrical conductivity of soil saturation extract.

After application of a reduced standard mineral fertilizer of $60 \mathrm{~kg} \mathrm{~N}, 40 \mathrm{~kg} \mathrm{~K}$ and $20 \mathrm{~kg} \mathrm{P}$ per ha, and after sowing the spinach seeds (Spinacea oleracea cv. Monopa), the experimental field was divided into twelve $4 \times 12 \mathrm{~m}$ plots, six plots for each of the two irrigation treatments, namely a control and a salt treatment. The control was irrigated with deionized water and the salt treatment received a salt solution at a concentration of $0.8 \mathrm{~g}$ salt per litre (equivalent to $12.6 \mathrm{mM}$ ) consisting of $\mathrm{NaCl}, \mathrm{Na}_{2} \mathrm{SO}_{4}$ and $\mathrm{CaCl}_{2}$ at a molar ratio of 20:1:0.5, respectively. This corresponds to the average salt content of water used for irrigation in this area. Water application was achieved by a manual sprinkler which was operated to maintain soil water content at $5 \mathrm{~cm}$ deep above $60 \%$ of the field capacity.

\subsection{Methods}

Nine weeks after emergence the plants were harvested for yield determination and analysis. Immediately after harvest the soil was sampled by auger to $30 \mathrm{~cm}$ deep. Soil subsamples from which visible roots were removed were used for chemical analysis. The preparation of soil saturation extract was carried out according to Richards [28]. The roots from further soil subsamples were carefully washed out of the soil for chemical analysis and root length determination by an intersect method as described by Tennant [31]. Root length data were calculated per unit soil volume to express soil rooting density as well as per unit shoot to give an estimate of the root absorbing potential available to the shoot. Metal concentration in soil, soil extracts and plant material was determined by atomic absorption analysis after microwave digestion as described by Padeken [25]. The presented results are mean values of six replicates. The least significant differences (LSD) between treatment means were calculated as a function of variance according to Snedecor [30].

\section{RESULTS AND DISCUSSION}

\subsection{Heavy metal accumulation in Nahda soils}

Heavy metal pollution of soils is increasing world wide [27]. In industrial countries, heavy metal pollution of soils and crops has been researched extensively. In contrast to industrial countries relatively little attention has so far been paid to heavy metal pollution of agricultural soils in developing countries where it is generally assumed that environmental pollution is mainly related to industrial activities. The present work demonstrates, however, that heavy metal pollution may proceed far away from industrial activities owing to recycling of waste water and the application of heavy metal contaminated fertilizers and composts.

As indicated in table $I I$ the soil $\mathrm{Ni}$ content at Nahda increased rapidly between 1972 and 1984 from 6.74 to $18.2 \mathrm{mg} \cdot \mathrm{kg}^{-1}$ by a factor of about three. During the same period the soil Cd concentration increased almost ten-fold. After 1984, the application of heavy metal contaminated canal sediments to Nahda soils was stopped. Nevertheless, the soil $\mathrm{Cd}$ and $\mathrm{Ni}$ concentration continued to increase, much more slowly, however. Unfortunately, there are no available records on heavy metal loads transferred to Nahda soils through canal sediment application. The slowdown of soil $\mathrm{Ni}$ and $\mathrm{Cd}$ accumulation after 1984 (table II) suggests, however, that canal sediment may have been the main source of soil heavy metal pollution.

\subsection{Soil salinization through irrigation}

At the Nahda area, the usual annual irrigation rate is about $5 \cdot 10^{6} \mathrm{~L} \cdot \mathrm{ha}^{-1}[12]$. With an average salt 
Table III. Dry matter yield, root development and nutrient content of spinach leaves as affected by salt water irrigation.

\begin{tabular}{lrrc}
\hline & Control & Salt & LSD $_{0.05}$ \\
\hline Dry matter yield $\left(\mathrm{g} \cdot \mathrm{m}^{-2}\right)$ & 189 & 197 & 18 \\
Root length density $\left(\mathrm{cm} \cdot \mathrm{L}^{-1}\right)$ & 66 & 102 & 14 \\
Root/Shoot $\left(\mathrm{cm} \cdot \mathrm{g}^{-1}\right)$ & 349 & 518 & 102 \\
Nutrient content & & & \\
(mmole $\cdot \mathrm{kg}^{-1}$ fresh wt.) & & & \\
$\mathrm{Na}$ & 16 & 111 & 14 \\
$\mathrm{~K}$ & 140 & 106 & 23 \\
$\mathrm{Ca}$ & 19 & 16 & 5.1 \\
$\mathrm{Mg}$ & 22 & 35 & 8.4 \\
$\mathrm{~S}$ & 20 & 38 & 7.3 \\
$\mathrm{P}$ & 18 & 26 & 7.9 \\
$\mathrm{~N}$ & 276 & 301 & 40 \\
$\mathrm{Cl}$ & 8 & 18 & 4.5 \\
\hline
\end{tabular}

$\operatorname{LSD}_{0.05}:$ least significant difference at $5 \%$ probability.

content of irrigation water of $0.8 \mathrm{~g} \cdot \mathrm{L}^{-1}$, this corresponds to an annual salt input of about $4000 \mathrm{~kg} \cdot \mathrm{ha}^{-1}$. The relatively moderate increase in soil salinity between 1972 and 1995 (table II) demonstrates, therefore, good salinity control practices. Nevertheless, it is evident from table II that the soil salt content has increased consistently with time. This was attributed partly to organic matter and clay enrichment which enhances water retention after irrigation and subsequent evaporation from topsoil [12].

Salt water irrigation at this salinity level showed no adverse effect on the growth of spinach. As shown in table III, the dry matter yield was even increased slightly while the root development was enhanced significantly by salt water application. A similar stimulating effect of moderate salinity on plant growth has been reported [9] for several salt tolerant plant species and may be related to a favourable osmotic effect of low salinity levels. In agreement with this interpretation, the increase in mineral element contents of spinach due to salt water irrigation (table $I I I)$ demonstrates a considerable ability for osmotic adjustment to salinization of the root environment. From the data of table III it is furthermore evident that Na plays the principal role in the osmotic adjustment of spinach.

\subsection{Salinity-Heavy metal interaction}

The rate of heavy metal uptake by plant roots depends on metal concentration at the root surface and on several uptake characteristics of the roots [2, 25]. The results of this work provide evidence that increasing salt concentration in the root environment affects both aspects independently.

As indicated in table $\mathrm{IV}$, the salt treatment affected the concentration of $\mathrm{Cd}$ and $\mathrm{Ni}$ in soil saturation extract differently. While the extractability of $\mathrm{Cd}$ was enhanced significantly, the $\mathrm{Ni}$ concentration was hardly affected by the salt treatment. The reason for this discrimination is not clear, but it may be attributed to different sorptive behaviour [29] of both metals, however.

In spite of differential solubility effects, the salt treatment enhanced the uptake of both metals by spinach considerably (table $V$ ). These results confirm previous findings with maize and ryegrass [13, 16]. Salinity-Heavy metal interactions are difficult to interpret, however, because of the many factors (table I) involved directly or indirectly in heavy metal uptake by plant roots which may be affected differently by soil and water salinity. An example of indirect salt effects on heavy metal uptake by plant roots is the modification of root development. Table III shows clearly that the salt treatment increased the root length and enhanced the soil rooting density as well as the root/shoot ratio considerably. The results presented in table $V$ indicate furthermore

Table IV. Salinity and metal content of soil saturation extract after harvest.

\begin{tabular}{llll}
\hline & Control & Salt & $\mathrm{LSD}_{0.05}$ \\
\hline Electrical conductivity $\left(\mathrm{dS} \cdot \mathrm{m}^{-1}\right)$ & 1.74 & 1.92 & 0.06 \\
Cd concentration $\left(\mu \mathrm{g} \cdot \mathrm{L}^{-1}\right)$ & 31 & 47 & 13 \\
Ni concentration $\left(\mu \mathrm{g} \cdot \mathrm{L}^{-1}\right)$ & 68 & 72 & 25 \\
\hline
\end{tabular}

$\mathrm{LSD}_{0.05}$ : least significant difference at $5 \%$ probability. 
Table V. Cd and Ni uptake and translocation in spinach as affected by salt water irrigation.

\begin{tabular}{|c|c|c|c|c|}
\hline Parameter & Element & Control & Salt & $\mathrm{LSD}_{000}$ \\
\hline $\begin{array}{l}\text { Shoot concentration } \\
\left(\mu \mathrm{g} \cdot \mathrm{g}^{-1}\right)\end{array}$ & $\begin{array}{l}\mathrm{Cd} \\
\mathrm{Ni}\end{array}$ & $\begin{array}{l}2.81 \\
12.8\end{array}$ & $\begin{array}{l}6.40 \\
28.2\end{array}$ & $\begin{array}{l}0.85 \\
4.10\end{array}$ \\
\hline $\begin{array}{l}\text { Root concentration } \\
\left(\mu \mathrm{g} \cdot \mathrm{g}^{-1}\right)\end{array}$ & $\begin{array}{l}\mathrm{Cd} \\
\mathrm{Ni}\end{array}$ & $\begin{array}{l}12.1 \\
24.3\end{array}$ & $\begin{array}{l}4.72 \\
10.5\end{array}$ & $\begin{array}{l}3.12 \\
3.20\end{array}$ \\
\hline $\begin{array}{l}\text { Total uptake } \\
\left(\mu \mathrm{g} \cdot \mathrm{m}^{-2}\right)\end{array}$ & $\begin{array}{l}\mathrm{Cd} \\
\mathrm{Ni}\end{array}$ & $\begin{array}{c}644 \\
2650\end{array}$ & $\begin{array}{l}1318 \\
5686\end{array}$ & $\begin{array}{l}190 \\
785\end{array}$ \\
\hline $\begin{array}{l}\text { Uptake } \\
\text { per unit root* } \\
\left(\mu \mathrm{g} \cdot \mathrm{m}^{-1}\right)\end{array}$ & $\begin{array}{l}\mathrm{Cd} \\
\mathrm{Ni}\end{array}$ & $\begin{array}{l}3.25 \\
13.4\end{array}$ & $\begin{array}{l}4.32 \\
18.7\end{array}$ & $\begin{array}{l}1.01 \\
2.80\end{array}$ \\
\hline $\begin{array}{l}\% \text { translocated } \\
\text { to shoot }\end{array}$ & $\begin{array}{l}\mathrm{Cd} \\
\mathrm{Ni}\end{array}$ & $\begin{array}{l}82 \\
91\end{array}$ & $\begin{array}{l}96 \\
98\end{array}$ & $\begin{array}{l}7.50 \\
8.38\end{array}$ \\
\hline
\end{tabular}

$\mathrm{LSD}_{0.05}$ : least significant difference at $5 \%$ probability.

* Based on root length density to $30 \mathrm{~cm}$ deep.

that soil salinity affected not only the morphological root characteristics but also the metal uptake per unit root length. This suggests that further physiological salt effects are involved. Helal et al. [13] referred to the effect of salinity on root permeability and attributed the increased metal uptake under saline conditions to an enhanced diffusive metal flux. An alternative mechanism which may be involved is a reduced retention of metals in the root tissue (table $V$ ). In agreement with this view saline conditions increased not only the uptake of $\mathrm{Cd}$ and $\mathrm{Ni}$ but also their translocation to the shoot.

\section{CONCLUSIONS}

The results of this work show that saline conditions, which are widespread in dry areas modify heavy metal behaviour both in soils and in plants. Some aspects of related interactions are still far from being well understood and need further research. This applies especially to the role of root exudates in heavy metal desorption and mobility in the rhizosphere of salt affected plants under field conditions. This work suggests furthermore that the risk of leachabilility of heavy metals from soils and their transfer to the food chain under saline conditions may be much greater than so far assumed.

Acknowledgements: This work was supported by the Federal Ministry of Education, Science, Research and Technology (BMBF) and by the German Academic Exchange Service (DAAD).

\section{REFERENCES}

[1] Arnold P.T., Kapustka L.A., Comparative uptake kinetics and transport of cadmium and phosphate in Phleum pratense-Glomus deserticolum associations, Environ. Toxicol. Chem. 12 (1993) 177-186.

[2] Barber S., Soil Nutrient Bioavailability, A Mechanistic Approach, John Wiley, New York, 1984.

[3] Bingham F.T., Sposito G., Strong J.E., The effect of sulphate on the availability of cadmium, Soil Sci. 141 (1986) 172-177.

[4] Bingham F.T., Strong J.E., Sposito G., Influence of chloride salinity on cadmium uptake by swiss chard, Soil Sci. 135 (1983) 160-165.

[5] Boyko H., Salinity and Aridity, Junk Publishers, The Hague, 1966.

[6] Bresler E., McNeal B.L., Carter D.L., Saline and Sodic Soils, Springer Verlag, Berlin, 1982.

[7] Denny H.J., Ridge I., Fungal slime and ist role in the mycorrhizal amelioration of zinc toxicity to higher plants, New Phytol. 130 (1995) 25l-257.

[8] Flowers T.J., Troke P.F., Yeo A.R., The mechanism of salt tolerance in halophytes, Annu. Rev. Plant Physiol. 28 (1977) 89-121.

[9] Greenway H., Munns R., Mechanisms of salt tolerance in nonhalophytes, Annu. Rev. Plant Physiol. 31 (1980) 149-190.

[10] Hagemeyer J., Waisel Y., Uptake of Cd and Fe by excised roots of Tamarix aphylla, Physiol. Plant. 77 (1989) 247-253.

[11] Helal H.M., Effects of sodium chloride on ionic relations, energy status and dry matter synthesis by various crop plant species, D.Sc.(Habil) thesis, Justus-Liebig University, Giessen, Germany, 1983.

[12] Helal H.M., Issa I., Low input concept for desert agriculture, in: Aly H. F., Nentwich D. (Eds.), 
German-Egyptian Seminar on Environmental Research, Forschungszentrum Julich, Germany, 1994, pp. 239-250.

[13] Helal H.M., Haque S.A., Ramadan A.B., Schnug E., Salinity-Heavy metal interactions as evaluated by soil extraction and plant analysis, Commun. Soil Sci. Plant Anal. 27 (1996) 1355-1361.

[14] Helal H.M., Mengel K., Nitrogen metabolism of young barley plants as affected by $\mathrm{NaCl}$ salinity and potassium, Plant Soil 51 (1979) 457-462.

[15] Helal H.M., Ragab M., Growth and nitrogen yield of Leucaena/maize mixed culture as affected by salt stress and gypsum, J. Plant Nutr. Soil Sci. 158 (1995) 211-216.

[16] Helal H.M., Ramadan A.B., Azam F., Heavy metal uptake by Lolium italicum and root mortality as affected by salt water irrigation, in: Prost R. (Ed.), Contaminated Soils, Inra, Paris, 1997, pp. 189-194.

[17] Helal H.M., Sauerbeck D., Carbon turnover in the rhizosphere, J. Plant Nutr. Soil Sci. 152 (1989) 211-216.

[18] Khattak R.A., Jarrell W.M., Effect of saline irrigation waters on soil manganese leaching and bioavailability to sugar beet, Soil Sci. Soc. Am. J. 53 (1989) 142-146.

[19] Kloke A., Sauerbeck D., Vetter H., The contamination of plants and soils with heavy metals and the transport of metals in terrestrial food chains, in: Nriagu J.O. (Ed.), Changing Metal Cycles and Human Health, Springer Verlag, Berlin, 1984, pp. 113-141.

[20] Lidon F.C., Henriques F.S., Effect of copper toxicity on growth and the uptake and translocation of metals in rice plants, J. Plant Nutr. 16 (1993) 1449-1464.

[21] Maas E.V., Salinity and citriculture, Tree Physiol. 12 (1993) 195-216.
[22] McLaughlin M.J., Palmer L.T., Tiller K.G., Beech T.A., Smart M.K., Increased soil salinity causes elevated cadmium concentrations in field-grown potato tubers, Environ. Qual. 23 (1994) 1013-1018.

[23] Nye P.H., Tinker P.B., Solute Movement in the Soil-Root System, Blackwell Scientific Publications, Oxford, 1977.

[24] Oconnor G.A., Oconnor C., Cline G.R., Sorption of cadmium by calcareous soils, Influence of solution composition, Soil Sci. Soc. Am. J. 48 (1984) 1244-1247.

[25] Padeken K., Schwermetallaufnahme verschiedener Pflanzenarten unter besonderer Berücksichtigung der $\mathrm{N}$ - und P-Ernährung, Diss. Fachbereich Agrarwissenschaften, Universität Göttingen, Germany, 1997.

[26] Petit C.M., Geijn S.C., In vivo measurement of cadmium $\left({ }^{115} \mathrm{Cd}\right)$ transport and accumulation in the stems of intact tomato plants (Lycopersicon esculentum, Mill.), I. Long distance transport and local accumulation, Planta 138 (1978) 137-143.

[27] Prost R., Contaminated Soils, Inra, Paris, 1997.

[28] Richards L.A., Diagnosis and improvement of saline and alkali soils, U.S. Dept. of Agriculture, Washington, 1954.

[29] Ross S.M.: Toxic Metals in Soil-Plant Systems, John Wiley, Chichester, UK, 1994.

[30] Snedecor G.W., Statistical Methods, Iowa State University Press, Ames, IA, USA, 1966.

[31] Tennant D., A test of a modified intersect method of estimating root length, J. Ecol. 63 (1975) 995-1001.

[32] White M.C., Decker A.M., Chaney R.L., Metal complexation in xylem fluid, I. Chemical composition of tomato and soybean stem exudate, Plant Physiol. 67 (1981) 292-300. 